\title{
BESSE, Maria Graciete. $O$ duplo fulgor do tempo. Évora: Editorial Licorne, 2019. 182 p.
}

Glória de Brito

Universidade Sénior de Almada (USALMA), Almada, Setúbal / Portugal mgloriabrito@gmail.com

Recebido em: 30 de setembro de 2019.

Aprovado em: 30 de novembro de 2019.

Maria Graciete Besse é sobretudo conhecida no panorama literário pela sua vasta e relevante obra ensaística. Contudo, a sua criação literária, menos divulgada, quer na ficção (conto e romance) quer na poesia, merece um lugar de destaque e de estudo exigente, pela qualidade da sua expressão lírica e pela abordagem de temáticas sociais e da realidade feminina, nas suas narrativas.

O duplo fulgor do tempo vem revelar um novo fôlego narrativo e uma grande maturidade no agenciamento dos factos diegéticos e na organização discursiva. Após uma pausa, a autora regressa à prosa de ficção, propondo ao leitor uma (re)presentação de duas épocas históricas, marcadas por acontecimentos e lugares duplamente tecidos em temporalidades distanciadas por duzentos anos.

A narração, organizada em vinte e um capítulos, desenvolve, em paralelo e de forma alternada, duas histórias protagonizadas por duas figuras femininas com o mesmo nome de Luísa, inseridas no mesmo espaço geográfico, a Caparica, mas em contextos socio-históricos distintos e classes sociais opostas: a nobreza do séc. XVIII e o campesinato da primeira metade do século vinte. 
No presente da enunciação, D. Luísa do Pilar de Noronha, protagonista de uma das histórias, é uma fidalga da família dos Condes de Arcos que vive no palacete da Quinta da Torre (lugar real), casada com Álvaro de Távora, conde de São Miguel, em 1731, apenas com treze anos e de quem tem onze filhos.

A Luísa da outra história é uma camponesa nascida no mesmo espaço geográfico, em 1926, viúva, que vive num lar de idosos, abandonada pelos filhos e netos, insatisfeita com a vida de rotina, decadência, vazio e tristeza, aguardando a morte.

Entre as duas personagens existe, todavia, uma continuidade na essencialidade das suas existências. Ambas são vítimas de uma sociedade regida por leis prepotentes e repressoras e por valores morais e religiosos discriminatórios e injustos, particularmente no que diz respeito à condição da mulher. Mergulhadas, uma na época absolutista, outra no Estado Novo, atravessam a vida subjugadas a um mesmo destino de rotina, obediência e resignação contida, imposto pelos "preceitos do pai, do marido ou do confessor". "Só os homens se podiam lançar no desconhecido e oferecerse à novidade, sem receios nem amarras" (p. 61). São mulheres infelizes, com sonhos reprimidos por não conseguirem libertar-se das teias do poder paternal ou conjugal, suportando a dor das infidelidades e o vazio da vida. Só a morte apaga o sofrimento, como sugere o encontro entre as duas, no capítulo final, de conotação afectiva e carga poética.

Ao longo da narração, as vozes das duas personagens vão reconstituindo, pela memória e anaforicamente, a cronologia dos acontecimentos ocorridos durante as suas vidas, num discurso entre ficção e história, sustentado por referências espácio-temporais e temáticas verosímeis. A escritora recria e cruza estes dois longos ciclos diacrónicos, num ritmo narrativo rápido, com grande concisão e intensidade, fornecendo um vasto conjunto de informações históricas, políticas e culturais ligadas a figuras e factos reais, representados na diegese.

Assim, a enunciação da personagem Luísa camponesa, na primeira pessoa gramatical, resgata o passado da sua infância, juventude e vida adulta na época da ditadura do Estado Novo e dos primeiros tempos do pós vinte e cinco de Abril. No seu discurso memorial, de registo oralizado e confessional, sob forma descontínua e fragmentária, emerge um conjunto de episódios relevantes da história recente do actual concelho de Almada. Destacamos, entre outros, a acção humanitária e cívica da Dona Infanta, afilhada do último rei de Portugal e neta de D. Miguel, 
no lugar de Murfacém, bem como o episódio do marinheiro que o pai escondeu no poço, implicado na sublevação dos barcos de guerra "Afonso de Albuquerque" e "Dão", em 1936, que conseguiu escapar à prisão ou desterro. Concomitantemente, a personagem vai formulando opiniões e avaliando as acções passadas que tecem a mentalidade da época.

Na história de Luísa de Noronha entra uma quantidade significativa de personagens e uma acumulação de factos, datas e cenários verídicos, associados à família real e à alta nobreza: os Távoras, os Arcos, os Alornas e outros. Aqui, a voz da protagonista, na terceira pessoa gramatical, é incorporada no discurso de um narrador não especificado, no qual se diluem os comentários de ambos e se tecem os variadíssimos episódios da intriga.

A narrativa da Fidalga é densa e, tal como a da Luísa camponesa, fragmentada. Porém, está carregada de memória psicológica, na medida em que a lembrança do passado é dominada pelo medo e presságio do trágico e cruel suplício dos Távora, seus familiares.

Esta premonição é simbolizada pela cena dos "corvos luciferinos" que esvoaçam sobre a cabeça da jovem Luísa, recorrente na enunciação.

A escritora exuma ainda desse passado o terramoto de 1755 e acontecimentos da história individual de Álvaro Távora, enquanto governador de Góias, dando a conhecer aspectos da acção colonizadora do Brasil, ressaltando o trabalho escravo e desumano na extração mineira.

É de salientar o uso de uma pontuação específica em sintonia com a recapitulação de situações anteriores, traduzida por ocorrências de expressões de carácter memorial ("lembro-me", "ainda me lembro", "por onde andarão agora...", "dizia-se”, "ainda o estou a ver"). Esta escolha assume um papel conectivo na religação das derivações trazidas pela memória, criando a ideia de sucessividade e encadeamento, sustentando deste modo a unidade narrativa.

Uma outra particularidade da arquitectura do romance reside na inserção, no corpo do texto, de diversos fragmentos de enunciados de natureza diversificada, assinalados a itálico, designadamente de citações, orações, diários, descrições de lugares, cartas, documentos oficiais, autos, preceitos de etiquetas, de práticas sociais e crenças e até imagens e um documento autêntico da página do Diário de Lisboa. 
Esta amálgama de excertos parece pretender validar a veracidade do texto. No entanto, alguns deles reenviam para o domínio da doxa, ilustrando as intrigas familiares ou políticas, as apreciações e juízos de valor, expressos por diferentes olhares, que constroem as vertentes ficcional e documental.

É igualmente de ressaltar o contributo deste romance para iluminar o passado histórico, simultaneamente nacional e local de Almada, com um novo fulgor. 